\title{
TRENDY A SMEROVANIE POPULAČNEJ POLITIKY NA SLOVENSKU V ROKOCH 1918 - 1945
}

\author{
PAVOL T I Š L I A R - BRANISLAV Š P R O C H A - EVA \\ ŠK O R VAN K O V Á
}

\begin{abstract}
TIŠLIAR, Pavol - ŠPROCHA, Branislav - ŠKORVANKOVÁ, Eva. Trends and Directions in Population Policy in Slovakia, 1918-1945. Historický časopis, 2019, 67, 1, pp.83-101, Bratislava.

The paper is concerned with the main changes of direction in population policy in Slovakia in the period 1918-1945. Gradual appearance and deepening of changes in reproductive behaviour in the framework of the demographic revolution was characteristic of this period. The number of births decreased and so did infant mortality. On the other hand, limited possibilities for application outside the primary sector forced many people of productive age to seek employment abroad. The population policy of inter-war Czechoslovakia was contradictory and unsystematic. On the one hand, it strove to raise the birth rate, especially in relation to the very low fertility in the western parts of the state, but on the other it promoted migration to solve the problem of unemployment. After the break up of Czechoslovakia and the formation of the Slovak state, various measures were introduced with the aim of increasing the population. However, these were not intended for the Jewish and Roma populations, which were subjected to racial persecution by law.

Key words: Population policy. Ideas on population. Demographic development. Slovakia. First half of the 20th century.
\end{abstract}

DOI: https://doi.org/10.31577/histcaso.2019.67.1.4

\section{Úvodom}

Populačná politika je súborom opatrení, ktoré ovplyvňujú reprodukčné správanie obyvatel'stva. V najširšom vnímaní ju predstavuje súbor všetkých verejných politík, ktoré komplexne zasahujú do mnohých oblastí života spoločnosti. ${ }^{1}$ Patrí sem popri oblasti zdravotníctva a sociálnej starostlivosti (z nej najmä starostlivost' o rodinu a špecificky o deti), migračná politika, ale aj hospodárska politika v celej svojej šírke, ktorej dôsledky mali a majú na vývoj populácie značný

1 TIŠLIAR, Pavol. Populačná politika a populačný vývoj na území Slovenska v rokoch 1938 1945 - metodologické východiská. In TIŠLIAR, Pavol (ed.). Populačné štúdie Slovenska I. Krakov: Spolok Slovákov v Pol'sku, 2013, s. 9 a n. ISBN 9788374906913 
vplyv. Významne pôsobí na populáciu aj bytová, školská a kultúrna politika a ich vybrané strategické ciele smerované k rozvoju spoločnosti. Bez významu nie je ani zahraničná politika, ktorá $\mathrm{v}$ istých etapách historického vývoja spoločnosti dokonca zohrala rolu jedného z primárnych faktorov.

Formovat' účinnú populačnú politiku, ktorá by dokázala ovplyvňovat' proces l'udskej reprodukcie pre potreby štátu a spoločnosti, ${ }^{2}$ znamená nájst' vhodné nástroje a zmysluplnú koncepciu smerujúcu k udržatel'nosti a určitej stabilizácii populačného vývoja. Populačnú politiku možno realizovat' dvoma spôsobmi, ktoré sa zväčša v praxi kombinujú a dopíňajú. Aktívna populačná politika je ciel'avedomým priamym zásahom do života spoločnosti smerovaným bud' propopulačne, teda predovšetkým snahami o zvýšenie pôrodnosti, d’alej zlepšovaním úmrtnostných pomerov, ako aj snahami aktívne zasahovat' do procesu emigrácie alebo antipopulačne, ak je pre štát a spoločnost' z rôznych dôvodov výhodné znižovanie dynamiky rastu, prípadne stabilizácia počtu obyvatel'ov. Druhým spôsobom je pasívny prístup k populačnej politike, ked' spoločnost' nereaguje alebo reaguje len na vzniknuté podnety a problémy. Častejšie je pre tento prístup charakteristická chýbajúca komplexnejšia koncepcia štátnej populačnej politiky.

Massimo Livi-Bacci poukázal na vplyv legislatívy, sociálnej, hospodárskej a rodinnej politiky, ktoré ovplyvňujú správanie sa obyvatel'stva pri prijímaní rozhodnutí, ako napríklad oženit' sa, mat' deti alebo rozhodnút' sa pre migráciu v rámci krajiny či smerom do zahraničia. Takto široko definovaná populačná politika potom zahíňa mnohé aspekty spoločenského života, právne predpisy týkajúce sa manželstva a rozvodu, reguláciu plodenia a antikoncepcie, zákony upravujúce vzt’ahy medzi rodinnými príslušníkmi a postavenie žien, opatrenia sociálnej politiky na ochranu matiek a detí i ustanovenia na zlepšenie ekonomického postavenia rodiny. ${ }^{3}$ Súbor rozličných opatrení pritom môžeme rozdelit' do troch väčších skupín: 1) opatrenia chrániace individuálne práva; 2) opatrenia upravujúce nerovnosti medzi rôznymi skupinami obyvatel'stva; 3) opatrenia preferujúce určitý typ správania, pričom $\mathrm{v}$ populačných politikách sa akcentuje predovšetkým posledná skupina opatrení. ${ }^{4}$

Problematika populačnej politiky $\mathrm{v}$ celej svojej šírke tak predstavuje rozsiahly komplex rôznych opatrení, smerovaných do rôznych spoločensko-kultúr-

2 KUČERA, Milan. Propopulační politka je krok správním směrem. In Propopulační politika - ano či ne: Sbornik textů. Ekonomicka, právo, politika, 2002, č. 21. Praha: CEP, 2002, s. 31. ISSN 1213-3299.

3 LIVI-BACCI, Massimo. Population policy in Western Europe. In Population studies: Journal of Demography, 1974, roč. 28, č. 2, s. 192. ISSN 0032-4728

4 Tamže, s. 192-193; tiež RÁKOSNÍK, Jakub - ŠUSTROVÁ, Radka. Rodina v zájmu státu. Populačni růst a instituce manželství v českých zemích 1918-1989. Praha: Nakladatelství Lidové noviny, 2016, s. 22. ISBN 9788074223785. 
no-sociálno-hospodárskych oblastí. V našom príspevku sa s ohl'adom na značne obmedzený priestor zameriame predovšetkým na východiská a charakteristiky širšej sociálnej (sociálno-zdravotnej) a migračnej politiky ako dvoch významnejších súčastí populačnej politiky na území Slovenska po vzniku Československej republiky a ich smerovanie do roku 1945. Tento časový úsek našich dejín predstavoval z hl'adiska vedenia populačnej politiky dva odlišné prístupy riešenia populačných otázok a samotnej koncepcie populačnej politiky. Pokým v medzivojnovom období pôsobili opatrenia v niektorých smeroch rozporuplne a nekoncepčne, po vyhlásení autonómie Slovenska a vzniku Slovenskej republiky $(1939$ - 1945) sa vytvorila pomerne jasne zameraná koncepcia populačnej politiky.

\section{Východiská medzivojnovej populačnej politiky v Československu}

Československá republika vnikla spojením dvoch hospodársky, spoločensky, kultúrne, ale rovnako aj populačne odlišných území. ${ }^{5}$ Rozdiel medzi západnou a východnou častou republiky sa navyše ešte prehĺbil pripojením Podkarpatskej Rusi. Tieto odlišnosti tvorili základné východiská aj pri formovaní populačnej politiky, ktorá sa prejavovala značnou mierou protichodnosti.

V novom štátnom útvare sa spojili populácie s rôznym smerovaním, reprodukčným správaním a v rozdielnej etape zmien starého demografického režimu, ktoré v českej populácii nastúpili podstatne skôr, ako pri populácii Slovenska a Podkarpatskej Rusi. Prejavy demografického prechodu sa v Česku vyskytli už v prvej polovici 19. storočia zvyšovaním sobášneho veku a v nasledujúcom období došlo aj k výraznejšiemu poklesu manželskej plodnosti, prejavujúcej sa približne od 80 . rokov 19 . storočia. ${ }^{6}$ Už na prelome 19. a 20. storočia v Česku vznikali prvé odborné názory reagujúce na tento pokles a úvahy o možnom dopade týchto zmien. Niektorí autori pritom priamo varovali pred depopuláciou Česka, ked’že manželská plodnost' tam poklesla v rokoch 1902 - 1911 až o 15 \%. Tieto názory sa d’alej stupňovali najmä v 30. rokoch 20 . storočia, ked' pokles plodnosti pokračoval. ${ }^{7}$ Dôvody zmien v demografickom vývoji Česka sa hl'adali

5 Podrobnejšie pozri analýzy demografických procesov: ŠPROCHA, Branislav - TIŠLIAR, Pavol. Plodnost' a celková reprodukcia obyvatel'stva Slovenska v rokoch 1919 - 1937. Bratislava: Stimul, 2008. ISBN 9788089236503; ŠPROCHA, Branislav - TIŠLIAR, Pavol. Vývoj úmrtnosti na Slovensku v rokoch 1919 - 1937. Bratislava: Stimul, 2008. ISBN 9788089236442; ŠPROCHA, Branislav - TIŠLIAR, Pavol. Náčrt vývoja sobášnosti na Slovensku v rokoch 1919 - 1937. Bratislava: Stimul, 2008. ISBN 9788089236381.

6 BOHÁČ, Antonín. Český problém populační a některé pozoruhodní jevy v naši měne přirozené. In Obzor národohospodářský. Praha: J. Otto, 1914, s. 73.

7 Pozri napr. BLÁHA, Arnošt I. Dnešni krise rodinného života. Brno, 1933; BOHÁČ, Antonín. Obyvatelstvo v Československé republice. In Československá vlastivěda, řada II. - Národopis. Praha: Sfinx, 1937, s. 1-96; BOHÁČ, ref. 6. 
v racionalizme, dosiahnutí určitého stupňa kultúry, v hospodárskej úrovni, ale aj v životnej úrovni obyvatel'stva (teória blahobytu). Antonín Boháč, popredný československý štatistik a demograf, označil tento jav ako sociálne a spoločenské hnutie. ${ }^{8}$ Vnímal ho teda, a treba konštatovat', že správne, ako masový, nie individuálny jav. Moderná demografia tento proces označuje ako demografický prechod (revolúciu), ktorá z pohl'adu procesu plodnosti prináša jej výrazný pokles, a to najmä v dôsledku obmedzovania počtu detí v rodinách. ${ }^{9}$ Tento proces, ktorý postupne prebiehal v celej Európe od 19. storočia, sa vyznačoval predovšetkým zmenou populačnej klímy, teda zmenami v postoji rôznych častí spoločnosti k otázkam vstupu do manželstva, reprodukčnému správaniu, počtu detí v rodine, k antikoncepcii, plánovanému rodičovstvu a pod. Populačná klíma pritom predstavuje súbor spoločensky akceptovaných hodnôt, týkajúci sa prakticky celého rodinného života. Jej formovanie je spravidla dlhodobé, má charakter výraznej zotrvačnosti a k zmenám dochádza zvyčajne až dlhodobým pôsobením rôznych, najmä hospodársko-sociálnych, kultúrnych a spoločenských zmien. Z uvedeného tak vyplýva, že zmeny $\mathrm{v}$ oblasti životnej úrovne či pôsobením populačnej politiky sa nemusia prejavit' $\mathrm{v}$ krátkodobom horizonte, ale až postupne, celkovou zmenou ,životného“ prostredia rodín.

Otázka návrhov na účinnú populačnú politiku v Česku, preto mala už v predvojnovom období výraznejšie propopulačné smerovanie. Jedným z príkladov $\mathrm{v}$ tomto ohl'ade bol aj 14 bodový program Karla Andrleho z roku 1918, ktorý sa snažil vymedzit' oblasti, ktorými by sa mala populačná politika v Česku uberat' a zastavit' tak proces poklesu plodnosti. Mala byt' zameraná najmä na: 1) ochranu žien v priemysle; 2) starostlivost' o dojčatá (poradenstvo a ústavy); 3) starostlivost' o chudobnú mládež; 4) ochranu nemanželských detí; 5) rozvoj mravnej výchovy (smerom k materstvu, láske k národu, proti prepychu); 6) opatrenia proti úpadku mládeže; 7) bytovú politiku, smerovaná k zdravému bývaniu; 8) vnútornú kolonizáciu; 9) boj proti nákazlivým ochoreniam, antikoncepcii;

8 BOHÁČ, ref. 6, s. 69-71.

9 Podrobne pozri ŠPROCHA, Branislav - TIŠLIAR, Pavol. Transformácia plodnosti žien Slovenska v 20. a na začiatku 21. storočia. Bratislava: Muzeológia a kultúrne dedičstvo, 2016, s. 19 a n. ISBN 9788089881024; TIŠLIAR, Pavol. Transformácia plodnosti na Slovensku v 19. a 20. storočí (teoretické a metodologické východiská z pohl'adu historickej demografie). In Slovenská štatistika a demografia, 2015, roč. 25, č. 2, s. 3-13 ISSN 1210-1095; ŠPROCHA, Branislav - TIŠLIAR, Pavol. Charakter plodnosti na Slovensku v medzivojnovom období. In Historická demografie, 2014, roč. 38, č. 1, s. 77-112 ISSN 0323-0937; FIALOVÁ, Ludmila PAVLÍK, Zdeněk - VEREŠ, Pavel. Fertility Decline in Czechoslovakia during the Last Two Centuries. In Population Studies, 1990, roč. 44, č. 1, s. 89-106. ISSN 0032-4728; COALE, Ansley, J. The Decline of Fertility in Europe from the French Revolution to World War II. In BEHRMANN, Samuel J. - CORSA, Leslie - FREEDMAN, Ronald (eds.). Fertility and Family Planning. Michigan: University of Michigan Press, 1969, s. 3-24. ISBN 9780472081264. 
10) zdravotné opatrenia proti všeobecnej úmrtnosti; 11) zavedenie zdravotných vysvedčení pred sobášom, ako nástroj boja proti pohlavným chorobám a genetickej degenerácii; 12) boj proti alkoholizmu; 13) odstránenie prekážok sobášom a napokon 14) zavedenie daňovej sústavy ul'ahčujúcej situáciu rodinám s det'mi. ${ }^{10}$

Na Slovensku možno počiatky zmien v reprodukčnom správaní hl'adat' na konci 19. storočia. Relatívne nízka úroveň manželskej plodnosti bola v Uhorsku známa už v 80. rokoch 19. storočia, no týkala sa len určitých regiónov s prítomnost'ou saského obyvatel'stva v Sedmohradsku a na Slovensku v Hontianskej župe, v Tekove a na Gemeri. ${ }^{11}$ Výraznejší pokles manželskej plodnosti sprevádzaný zmenou populačnej klímy badat' zretel'ne na Slovensku najmä od prvej dekády 20. storočia, prehíbil sa počas 1 . svetovej vojny a pokračoval po odznení povojnovej kompenzačnej fázy v medzivojnovom období. ${ }^{12}$ Výraznejšie znižovanie manželskej plodnosti na Slovensku v medzivojnovom období neostalo bez odozvy. Všimol si ho napríklad aj významný sociálne cítiaci lekár a univerzitný profesor Alojz J. Chura, ktorý sa angažoval najmä v oblasti starostlivosti o deti a mládež na Slovensku. ${ }^{13}$

Môžeme predpokladat', že východiskom k zmenám populačnej klímy na Slovensku bola predovšetkým spoločensko-hospodárska transformácia, ku ktorej došlo v 2. pol. 19. storočia. Zdroj obživy väčšiny obyvatel'stva na Slovensku závisel v prevažnej miere od primárneho sektora. ${ }^{14}$ Výhodou pri hospodárení na pôde bol dostatok pracovných rúk, teda početná rodina. Táto devíza sa však začala menit' na nevýhodu, ked' sa postupne zmenili pomery vo vlastníctve pôdy, čo napokon viedlo k d’alšiemu dedeniu a deleniu pôdy v 2. pol. 19. storočia, až

10 ANDRLE, Karel. Směrnice a cíle české politiky populační. In Ochrana mládeže, 1918, roč. 8, č. 8, s. 241-248; tiež RÁKOSNÍK - ŠUSTROVÁ, ref. 4, s. 18-19.

11 K problematike rodín so zúženou reprodukciou na Slovensku pozri napr. BOTIKOVÁ, Marta. Regulácia pôrodnosti. In BOTIKOVÁ, Marta - ŠVECOVÁ, Soňa - JAKUBÍKOVÁ, Kornélia (eds.). Tradicie slovenskej rodiny. Bratislava: VEDA, 1997, s. 148-160. ISBN 9788022404616.

12 Tamže, s. 23-25.

13 CHURA, J. Alojz. Slovensko bez dorastu? I. diel. Bratislava: Rol'nícka osveta, 1936; CHURA, J. Alojz - KIZLINK, Karol. Slovensko bez dorastu? II. diel, čast' 2. Bratislava: Rol'nícka osveta, 1939; CHURA, J. Alojz. Slovensko bez dorastu? II. diel, čast' 1. Bratislava: Rol'nícka osveta, 1938.

14 JANTO, Juraj. Salašný chov oviec v Detve a na Slovensku. In Muzeológia a kultúrne dedičstvo, 2016, roč. 4, č. 2, s. 95-97. ISSN 1339-2204; JANTO, Juraj. Slovenské bryndziarstvo a vagačovská výrobňa v Detve. K 230. výročiu vzniku prvej bryndziarne. In Muzeológia a kultúrne dedičstvo, 2017, roč. 5, č. 2, s. 51-59. ISSN 1339-2204; zmeny vo vzt'ahu k reprodukcii pozri podrobnejšie v práci ŠPROCHA, Branislav - TIŠLIAR, Pavol. The fertility of women in the primary sector in Slovakia according to censuses conducted between 1900 and 2001 years. In Bylye gody, 3/2015, s. 625-662. ISSN 2310-0028. 
k existencii nesebestačných vidieckych hospodárstiev a k vzniku nezamestnanosti. Výsledkom bola agrárna prel'udnenost' a tlak na vyhl'adanie zamestnania mimo primárny sektor. Ked’že však rozvoj priemyslu postupoval v Uhorsku pomalým tempom a neumožňoval zamestnat' uvol'nené pracovné rezervy, relatívne prel'udnenie slovenského vidieka vyústilo do masového vyst'ahovalectva za prácou. ${ }^{15}$ Zároveň sa v 2. pol. 19. storočia začali postupne zlepšovat' úmrtnostné pomery. Týkalo sa to aj detskej zložky, hoci z európskeho hl'adiska zostávala u nás dojčenská a detská úmrtnost' nad'alej na vel'mi nepriaznivých úrovniach. Kombináciou hospodárskych zmien, posunov v procese úmrtnosti, spoločenskej transformácii sa znižoval aj tlak na manželský pár „,rodit’ deti do zásoby“ (tzv. teória A. Queteleta o náhradných det'och). ${ }^{16} \mathrm{Za}$ týchto podmienok sa stávala početná rodina skôr prít’ažou, vyšší počet detí nevýhodou, čo z dlhodobejšieho hl'adiska naštartovalo proces výrazných populačných zmien. Tie postupne vyvrcholili zmenami v populačnej klíme, smerujúcej k prechodu k modelu rodín s menším počtom detí. Významnou brzdou nástupu týchto zmien bola nepochybne vysoká religiozita obyvatel'stva a rezervovaný, resp. odmietavý postoj cirkví k antikoncepčným praktikám, nižšia gramotnost' obyvatel'stva, nízky stupeň urbanizácie, ako aj pevné kontrolné mechanizmy rurálnych spoločenstiev.

Pričlenené územie Podkarpatskej Rusi malo podobný populačný vývoj ako Slovensko, no v časovaní nástupu transformačných zmien sa ešte viac oneskorovalo. Vysoká manželská plodnost' zostávala aj v medzivojnovom období a až v 30. rokoch 20. storočia môžeme identifikovat' nástup zmien v reprodukčnom správaní, v kontexte posunov populačnej klímy. ${ }^{17}$ Pretrvávajúca vysoká plodnost' Podkarpatskej Rusi sa azda najmarkantnejšie prejavila tým, že obyvatel'stvo tohto územia patrilo $\mathrm{v}$ medzivojnovom období vôbec $\mathrm{k}$ vekovo najmladším v Európe. ${ }^{18}$ Výrazná závislost' na primárnom sektore a podmienenost' zmenami, ktoré v ňom nastali, vyústili rovnako ako na Slovensku do masového vyst’ahovalectva za prácou. ${ }^{19}$

15 TIŠLIAR, Transformácia plodnosti..., ref. 9, s. 5-7; TIŠLIAR, Pavol. K disproporciám a protichodnosti populačnej politiky v medzivojnovom Československu a jej prejavom na Slovensku. In TIŠLIAR, Pavol - ŠPROCHOVÁ, Terézia - VARGOVÁ, Lenka (eds.). Populačné štúdie Slovenska 7. Bratislava: Muzeológia a kultúrne dedičstvo, 2015, s. 68-69. ISBN 9788097171599; podrobne tiež HOLEC, Roman. Pol'nohospodárstvo na Slovensku v poslednej tretine 19. storočia. Bratislava: VEDA, 1991. ISBN 8022403202.

16 TIŠLIAR, Transformácia plodnosti..., ref. 9, s. 7.

17 ŠPROCHA, Branislav - ŠMIGEL, Michal - TIŠLIAR, Pavol. Reprodukčné správanie obyvatel'ov Podkarpatskej Rusi. In TIŠLIAR, Pavol (ed.). Populačné štúdie Slovenska 9. Bratislava: Muzeológia a kultúrne dedičstvo, 2016, s. 22. ISBN 9788089881017.

18 ŠPROCHA, Branislav - TIŠLIAR, Pavol. Populačný vývoj Podkarpatskej Rusi I. Demografická reprodukcia. Bratislava: Infostat, 2009, s. 67 a n. ISBN 9788089398119.

19 ŠVORC, Peter. Krajinská hranica medzi Slovenskom a Podkarpatskou Rusou (1919 - 1939). 
Načrtnutý predvojnový vývoj obyvatel'stva neskoršej Československej republiky teda vykazoval mnohé špecifiká a rozdiely, pričom je potrebné upozornit', že existovali ešte d’alšie na nižšej, regionálnej úrovni. ${ }^{20}$ Zohl'adnit' uvedené diferencie a z nich vyplývajúce rôzne potreby vyžadovalo osobitné prístupy, na ktoré mala či mohla účinná populačná politika reagovat'. Zjednodušene, pokým v západnej časti republiky bol záujem predovšetkým o zastavenie prepadu plodnosti a o oživenie reprodukcie, východná čast' bola v situácii, ked' obyvatel'stvo, ktoré nemalo dostatočné možnosti obživy, vykazovalo relatívnu prel'udnenost' a pokračujúce migračné straty aj v medzivojnovom období, napriek postupnému poklesu manželskej plodnosti.

\section{Základné prejavy protichodnosti populačnej politiky v medzivojnovom ob- dobí}

Existenciu rozdielnych potrieb pri riešení populačných problémov Československa nebolo možné zohl'adňovat' v základných rysoch osobitne pre západnú a východnú čast' republiky. Predstava, že by sa v Česku vykonávala len aktívna propopulačná politika, podporujúca zakladanie rodín, smerujúca z hl'adiska zvyšovania životnej úrovne, štátnych podpôr a pod. k stabilizácii úrovne manželskej plodnosti a postupnému oživeniu reprodukčného procesu a na druhej strane antipopulačne vedená politika vo východnej časti Československa, ktorá by prispela k rýchlejšiemu znižovaniu plodnosti, bola nereálna. Je azda zbytočné špekulovat' nad tým, aký efekt by mal takýto priamy prístup decíznej sféry. Namiesto toho bol do praxe uvedený akýsi hybridný model viacerých protichodných opatrení. Na jednej strane totiž dochádzalo $\mathrm{k}$ značnému úsiliu o podporu rodiny, zameranú špeciálne na starostlivost' o deti a mládež, ${ }^{21}$ čo vychádzalo aj z úsilia zvyšovat' počet obyvatel'ov umelo vytvorenej československej národnosti a posilňovat' československé obyvatel'stvo v strednej Európe. Išlo o logický zámer, ked’že Československo patrilo $\mathrm{k}$ štátom $\mathrm{s}$ početným zastúpením národnostných menšín. ${ }^{22} \mathrm{Na}$ druhej strane bola súčasne vedená politika smerujúca $\mathrm{k}$ vedomej regu-

Prešov: Universum, 2003, 92 a n. ISBN 8089046169.

20 Regionálne disproporcie pozri podrobne v spomenutých prácach ŠPROCHA - TIŠLIAR, ref. 5.

21 Podrobnejšie pozri HRNČIAROVÁ, Daniela. Sociálno-zdravotné aktivity Krajinského ústredia starostlivosti o mládež na Slovensku v Bratislave v prvej polovici 20. storočia. In TIŠLIAR, Pavol - ŠPROCHOVÁ, Terézia - VARGOVÁ, Lenka (eds.). Populačné štúdie Slovenska 7. Bratislava, Muzeológia a kultúrne dedičstvo, 2015, s. 107-120. ISBN 9788097171599; HRNČIAROVÁ, Daniela. Slovensko bez dorastu? od A. Churu a populačná politika na Slovensku na prelome 30. a 40. rokov 20. storočia. In TIŠLIAR, Pavol (ed.). Populačné štúdie Slovenska 6. Bratislava: Muzeológia a kultúrne dedičstvo, 2015, s. 7-32. ISBN 9788097171575.

22 KOUBEK, Josef. Populační politika v právních předpisech Československé republiky v le- 
lácii populácie. ${ }^{23}$ Táto vedomá regulácia sa najmarkantnejšie dotýkala charakteru migračnej politiky, ked' republiku aj za aktívnej pomoci ústredných orgánov Československa natrvalo opustili, najmä v dvadsiatych rokoch, desiatky tisíc vyst’ahovalcov. ${ }^{24}$ Väčšina z nich pritom pochádzala zo Slovenska a Podkarpatskej Rusi, kde emigrácia nadobudla masový charakter už v poslednej štvrtine 19. storočia. Táto kombinácia protichodných opatrení bola do značnej miery výsledkom chýbajúcej účinnej koncepcie populačnej politiky. Prijímaná legislatíva formujúca sociálnu, zdravotnú, migračnú a rodinnú politiku v užšom slova zmysle, bola skôr reakciou ex-post na existujúce problémy v spoločnosti, ako výsledok dlhodobo koncipovaných zámerov, stojacich na analytickom poznaní a prognózach vývoja v jednotlivých oblastiach spoločenského a hospodárskeho života.

Mnohé propopulačné opatrenia v Československu jednoznačne smerovali k populacionizmu. Jeho základnou myšlienkou bolo kladenie dôrazu na početnost' obyvatel'stva $v$ kontexte sily a rozvoja krajiny. Teda rozvoj štátu a jeho blahobyt priamo závisel od zvyšovania počtu obyvatel'stva. ${ }^{25}$ Populacionizmus možno badat' najmä v legislatívnych opatreniach v oblasti sociálnej a sociálno-zdravotnej starostlivosti o matky a deti, vyživovacích príspevkov (prídavkov) vybraným zamestnancom, v platenej dovolenke, v oblasti ochrany rodiny, adopcii a pod., ktoré v mnohých prípadoch Československá republika podrobne riešila ako jedna z prvých krajín vo svete. ${ }^{26}$ Propopulačné myšlienky a opatrenia boli sústredené aj v zdravotnej politike, ktorá sa koncentrovala nielen na zníženie chorobnosti obyvatel'stva, napr. opatreniami proti šíreniu rôznych chorôb, ale viedla aj aktívnu osvetu k zlepšeniu hygieny, k prevencii, ale aj d’alšiemu zni-

tech 1918-1938. In Demografie, 1980, roč. 22, č. 2, s. 135. ISSN 0011-8265.

23 ŠUBRTOVÁ, Alena. Dějiny populačního myšlení v českých zemích. Praha: Česká demografická společnost, 2006, s. 186. ISBN 8023983695.

24 Podrobnejšie pozri napr. TIŠLIAR, Pavol. Formy organizovania vyst'ahovalectva zo Slovenska po vzniku Československej republiky. In ŠMIGEL, Michal - TIŠLIAR, Pavol a kol. Migračné procesy Slovenska (1918 - 1948). Banská Bystrica: Belianum, 2015, s. 56-71. ISBN 9788055708041 . Vyst’ahovalecký zákon bol v Československu prijatý v roku 1922 pod číslom 71 následne po vysokom náraste záujmu o vyst’ahovalectvo. Národní archiv České republiky v Prahe (d’alej NAČR), f. Ministerstvo vnitra I. - Stará registratura, 1918 - 1953 (d’alej f. MV-SR), sign. 8794/1921; 13450/IV. ai 1921.

25 JURČOVÁ, Danuša. Slovník demografických pojmov. Bratislava: Infostat, 2005, s. 12. ISBN $8085659409 .$.

26 KOUBEK, ref. 22, s. 126. Materská dovolenka a pracovná ochrana ženy, detí, vybrané vyživovacie príspevky, ochrana rodiny a pod. bola právne zabezpečená viacerými zákonmi, napr. z. č. $689 / 1920$ Sb. z. a n.; z. č. $221 / 1924$ Sb. z. a n.; z. č. 184/1928 Sb. z. a n.; z. č. 185/1928 Sb. z. a n.; z. č. 103/1926 Sb. z. a n.; z. č. 91/1918 Sb. z. a n.; z. č. 89/1920 Sb. z. a n.; z. č. 104/1926 Sb. z. a n.; z. č. 530/1919 Sb. z. a n.; z. č. 67/1925 Sb. z. a n.; z. č. 262/1921 Sb. z. a n. a i. 
žovaniu úmrtnosti obyvatel'stva. ${ }^{27}$ Osobitný význam sa kládol najmä na znižovanie detskej a dojčenskej úmrtnosti. ${ }^{28} \mathrm{~V}$ sociálno-zdravotnej oblasti mali väčší význam aj opatrenia v oblasti bezpečnosti práce, zdravotné, úrazové a starobné poistenie a pod..$^{29} \mathrm{Za}$ propopulačné opatrenia možno určite $\mathrm{v}$ kontexte sociálno-zdravotnej agendy označit inštitucionalizáciu starostlivosti o deti a mládež, hoci sa ich činnost' priamo na znížení detskej a dojčenskej úmrtnosti napokon výraznejšie neprejavila. ${ }^{30} \mathrm{Na}$ uplatnenie opatrení v sociálnej oblasti totiž mala významný vplyv najmä hospodárska situácia a možnosti, ktoré na ich realizáciu ponúkala. $^{31}$

Protichodne smerovali opatrenia $\mathrm{v}$ spomenutej migračnej politike. Tá mala pritom už svoj predvojnový názorový vývoj. V tomto smere a vo vzt’ahu k neskoršiemu formovaniu migračnej politiky v Československu bol azda zaujímavý názor A. Boháča z roku 1914. Boháč videl v živelnom vyst’ahovalectve a v relatívnom prel'udnení možnost' „národnej a jazykovej expanzie“, ktorú by pri vytváraní kompaktnejšieho osídlenia mohli predstavovat' zahraničné kolónie. ${ }^{32}$ Možnost' takejto „expanzie“ videl najmä v blízkosti pôvodného národného prostredia, teda nie $\mathrm{v}$ mimoeurópskom prostredí, kde $\mathrm{v}$ budúcnosti predpokladal rýchlejšiu jazykovú asimiláciu a zánik takýchto kolónií. V medzivojnovom ob-

27 V oblasti zdravotníctva na Slovensku v tomto smere fungovala Expozitúra ministerstva verejného zdravotníctva MVSR - Slovenský národný archív v Bratislave (d’alej SNA), f. Expozitúra Ministerstva verejného zdravotníctva, 1919 - 1929 (d’alej f. EMVZ).

28 Z. č. 412/1919 Sb. z. a n., vl. nar. č. 298/1920 Sb. z. a n., z. č. 241/1922 Sb. z. a n., z. č. 191/1923 Sb. z. a n., vl. nar. 193/1923 Sb. z. a n., z. č. 116/1934 Sb. z. a n., vl. nar. 50/1920 Sb. z. a n., vl. nar. 239/1920 Sb. z. a n., vl. nar. 161/1927 Sb. z. a n. Syntetický pohl'ad na túto oblast' prinášajú práce BOKESOVÁ-UHEROVÁ, Mária. Dejiny zdravotníctva na Slovensku. Bratislava: Osveta, 1989. ISBN 8021700041; FALISOVÁ, Anna. Medzivojnové Slovensko z pohl'adu zdravotného a sociálneho. ZEMKO, Milan - Bystrický, Valerián (eds.). In Slovensko v Československu. (1918 - 1939). Bratislava: Veda, 2004, s. 365-416. ISBN 802240795; FALISOVÁ, Anna. Zdravotníctvo na Slovensku v medzivojnovom obdobi. Bratislava: Veda, 1999. ISBN 8022405442.

29 Okrem zákazu nočnej práce žien, detí a pod. vl. nar. 60/1929 Sb. z. a n. zriad’ovala Komisiu pre technickú a zdravotnú ochranu zamestnancov; oblast' poistenia: z. č. 207/1919 Sb. z. a n.; z. č. 268/1919 Sb. z. a n.; z. č. 272/1919 Sb. z. a n.; z. č. 89/1920 Sb. z. a n.; z. č. 689/1920 Sb. z. a n.; z. č. 221/1924 Sb. z. a n.; z. č. 148/1925 Sb. z. a n.; z. č. 221/1925 Sb. z. a n.; z. č. 26/1929 Sb. z. a n.; z. č. 43/1929 Sb. z. a n.; z. č. 99/1932 Sb. z. a n.

30 Pozri podrobnejšie ŠPROCHA, Branislav - TIŠLIAR, Pavol. Inštitucionalizácia sociálnej starostlivosti o deti a mládež na Slovensku v 20. a 30. rokoch 20. storočia. In Od špitála k nemocnici: Zdravotníctvo, sociálna starostlivost' a osveta v dejinách Slovenska. Bratislava: SNA, 2013, s. 436-445. ISBN 9788097066666.

31 Pozri bližšie, napr. FALISOVÁ, Anna. Zmiernenie biedy. Aktivity medzivojnovej ČSR pre sociálne a hmotne slabých. In História, 2003, roč. 3, č. 4, s. 26-29. ISSN 1335-8316.

32 BOHÁČ , ref. 6, s. 9-13. 
dobí sa táto téma otvorila znova po vzniku Československého ústavu zahraničného (1928), ako jedna z reakcií na rezignovaný postoj migračnej politiky v Československu. ${ }^{33}$

Prvá svetová vojna a prvé roky po vzniku Československa značne znížili objem zahraničnej emigrácie. Povojnová transformácia hospodárskych pomerov a postupná profilácia východných častí republiky ako odbytiska tovarov českých krajín neprispievala k výraznejšiemu zlepšovaniu zamestnanosti obyvatel'stva. $\mathrm{K}$ zhoršeniu situácie prispela aj povojnová vlna reemigrantov. Medzi aktívne formy riešenia situácie opätovne $\mathrm{v}$ hromadnej miere začala patrit' najmä ekonomická emigrácia do zahraničia. Prispeli k tomu aj legislatívne úpravy, ktoré tento problém postavili na princípe slobodného st'ahovania. ${ }^{34}$

V súvislosti s charakterom pracovnej migrácie je dôležité si uvedomit', že táto významnou mierou ovplyvňovala aj populačný vývoj a reprodukciu obyvatel'stva. Zúčastňovali sa jej totiž osoby v produktívnom a reprodukčnom veku, živitelia rodín, ktorých často po získaní stabilného zamestnania nasledovali aj ostatní členovia rodín. Negatívne na reprodukciu tiež vplývalo dlhé odlúčenie manželov a partnerov pracujúcich v zahraničí. Výsledkom tak nebola len trvalá migračná strata, ale aj zmenšovanie reprodukčného potenciálu. Uvedený jav však mal aj svoju druhú stránku. Československo takto síce strácalo čast' produktívnej a reprodukčnej zložky, no prostredníctvom zahraničnej emigrácie sa aspoň čiastočne darilo zmierňovat' negatívne dôsledky relatívneho preludnenia, nezamestnanosti, ktoré nebolo $\mathrm{v}$ daných podmienkach možné riešit' aktívnymi politickými a hospodárskymi opatreniami.

Aj oficiálne stanovisko popredných československých politikov k problematike zahraničnej emigrácie bolo v mnohých ohl'adoch rozporuplné. Čast’ z nich istým spôsobom schval'ovala a pozitívne prijímala vyst'ahovalectvo, druhá ho vnímala so znepokojením a videla $\mathrm{v}$ ňom straty nielen populačné, ale aj ekonomické. ${ }^{35}$ Migračná politika, ktorá sa napokon v praxi realizovala, bola akýmsi kompromisom medzi týmito dvomi názorovými prúdmi. Už začiatkom 20. rokov sa začala organizovat' „účinná pomoc" migrantom odchádzajúcim z Československa, ktorá mala usmerňovat migračný prúd. ${ }^{36}$ Prejavilo sa to najmä v oblasti právnej ochrany migrantov, $\mathrm{v}$ zabezpečení a ul'ahčení ich odchodu z krajiny, a to napríklad zriadením zdravotnej stanice Svatobořice, migračného tábora Libeň

33 Archiv Národního muzea v Prahe (d’alej ANM), os. f. Antonín Boháč (d’alej of. A. Boháč), kartón (d’alej k.) 5.

34 Z. č. $71 / 1922 \mathrm{Sb}$. z. a n.

35 V tejto súvislosti možno upozornit' na viaceré rozpravy, interpelácie a návrhy poslancov Národného zhromaždenia, ktoré sa v poslaneckej snemovni riešili od roku 1920.

36 ANM, of. A. Boháč, k. 5, nedat. list J. Auerhana, predsedu Československého ústavu zahraničného, adresovaný Predsedníctvu ministerskej rady v Prahe. 
a pod. ${ }^{37}$ Opatrenia tak vychádzali z myšlienky uvedenej už v dôvodovej správe k vyst'ahovaleckému zákonu z roku 1921: ,... správne riadit' vyst'ahovalecký prúd - to je potrebné k účinnej štátnej vyst’ahovaleckej politike “. ${ }^{38}$

Lev Zavřel, pôsobiaci na Ministerstve sociálnej starostlivosti v Prahe, na porade o problémoch vyst’ahovalectva v roku 1928 konštatoval, že ak sa nemajú zhoršit' sociálne a zárobkové pomery v Československu a má ostat' zachovaná životná úroveň širokých vrstiev obyvatel'stva, je vyst'ahovalectvo pre Československú republiku nevyhnutné. Migráciu považoval za ,nutnú ventiláciu “ odstraňujúcu možné príčiny rôznych hospodárskych a sociálnych konfliktov, ktorým sa takto vlastne v Československu predchádzalo. Zavřel priamo hovoril o disparite medzi početným rastom obyvatel'stva a možnost'ami obživy. ${ }^{39} \mathrm{Z}$ hl'adiska populačných teórií možno $\mathrm{v}$ týchto a podobných názoroch vidiet' zrejmé prvky malthuzianizmu, v ktorom sa zdôrazňujú limity v populačnom raste zabraňujúce znižovaniu životnej úrovne a neomalthuzianizmu, ktorý kladie do popredia otázky regulácie plodnosti, napr. účinným zákonodarstvom, pre zabezpečenie ekonomického blahobytu spoločnosti. ${ }^{40}$

$\mathrm{V}$ podobnom duchu argumentoval aj A. Boháč, ktorý sa v medzivojnovom období stal uznávanou autoritou v oblasti populačného vývoja Československa a bol tvorcom metodiky úspešných medzivojnových cenzov na štatistickom úrade v Prahe. Ten zaradil Československo medzi krajiny, v ktorých práve vyst’ahovalectvo patrilo $\mathrm{k}$ jedným $\mathrm{z}$ hlavných prostriedkov na riešenie populačného problému. Vyst’ahovalectvo zo Slovenska považoval za východisko z agrárnej prel'udnenosti vidieka a spôsob riešenia vysokej nezamestnanosti v krajine. ${ }^{41}$

V rozporne s uvedeným možno vnímat' prácu verejnej správy na Slovensku v medzivojnovom období. Už od začiatku 20. rokov totiž mali orgány verejnej správy dlhodobo, aktívne a „primeraným spôsobom“ odhovárat' obyvatel'stvo od odchodu do zámoria. ${ }^{42} \mathrm{Je}$ pritom logické, že riešenie problému vyst'ahovalectva

37 Podrobnejšie pozri TIŠLIAR, ref. 20, s. 59 a n.; NAČR, f. MV-SR, sign. č. 76560/1921; sign. č. 10269/A-1921.

38 Poslanecká sněmovna NSRČ 1921. Parlamentná tlač 3001, vládny návrh zákona o vyst’ahovalectve a dôvodová správa k návrhu. <https://www.nrsr.sk/dl/Browser/Document?documentId=22249>; MVSR - Slovenský národný archív v Bratislave (SNA), f. Krajinský úrad v Bratislave, 1928 - 1940, sign. 16849/1936 prez.

39 ZAVŘEL, Lev. Vystěhovalectví. In Československé vystěhovalectví: jeho prričiny, důsledky a vyhlídky. Praha, 1928, s. 17-19.

40 JURČOVÁ, ref. 25, s. 11.

41 BOHÁČ, Antonín. Otázka populační a vystěhovalectví. In Československé vystěhovalectví: jeho príčiny, dưsledky a vyhlidky. Praha 1928, s. 24.

42 Podrobnejšie pozri napr. obežník MPS adresovaný župným úradom na Slovensku 21. júna 1920. MVSR - Štátny archív v Nitre so sídlom v Ivanke pri Nitre, f. Župa Nitra I., 1919 1922, sign. č. 914/1920 prez. 
rozvojom hospodárstva (najmä priemyslu a obchodu, investíciami a pod.) na Slovensku bolo navrhované predovšetkým slovenskými politikmi a národohospodármi, ked’že išlo o oblasti, z ktorých pochádzali, a ktoré verejne zastupovali. ${ }^{43}$

Nebolo pritom t'ažké pomenovat' problémy, ktoré viedli $\mathrm{k}$ vyst'ahovaleckej kríze. Rovnako nebol problém s pomenovaním možností, ktoré by vyst'ahovalectvu dokázali čelit'. ${ }^{44}$ Chýbali však prostriedky k realizácii takýchto opatrení. Do popredia sa tak dostávala myšlienka zriad’ovania československých zahraničných kolónií, s ktorými by bolo možné udržiavat' kontakty nielen spoluprácou v hospodárskej oblasti a pri vzájomnom obchode, ale aj v oblasti šŕrenia kultúry a pod. Práve tieto oblasti mal sprostredkovat' už spomenutý Československý ústav zahraničný. ${ }^{45}$ Snahy o toto „riadené“ kolonizovanie sveta československým obyvatel'stvom je však možné skôr vnímat' ako snahu o zakrytie neschopnosti koncepčne riešit' vyst'ahovalectvo vo vlastnej krajine.

V spojitosti s medzivojnovým Československom sa dá poukázat' na absenciu premyslenej koncepcie štátnej populačnej politiky. Opatrenia vyznievali len ako dodatočné reakcie na problémové situácie a oblasti verejného života, ktoré v spoločnosti nastali. V úplnom protiklade tak stojí nasledujúce obdobie populačných dejín Slovenska, ktoré nastalo prakticky od konca roku 1938. Prinieslo principiálne odlišne koncipovanú populačnú politiku, v ktorej sa síce rovnako stretli propopulačné a antipopulačné názory, no v úplne rozdielnom kontexte a za iných podmienok, so silným zahraničným ideologickým vplyvom.

\section{Zmeny populačnej politiky v rokoch 1938 - 1945}

V rokoch 1938 až 1945 prežila populácia Slovenska viaceré významné zmeny, až by sa dalo povedat' zásadné otrasy, ktoré mali dopad na celkový populačný vývoj, ale aj úplnú zmenu smerovania populačnej politiky. Mníchovská dohoda, autonómia Slovenska, Viedenská arbitráž na jeseň 1938 a napokon vyhlásenie Slovenského štátu v marci 1939 vytvorili úplne rozdielne spoločenské podmienky ako v predchádzajúcom období, podmienené navyše nielen politicko-hospodárskym podriadením Slovenska vplyvom nemeckej tretej ríše, ale aj vojnovým konfliktom, ktorého efekt bol väčšinu z predmetného obdobia skôr nepriamy.

Hned' na úvod je potrebné povedat', že viaceré opatrenia realizované v nemeckej tretej ríši inšpirovali slovenských politikov. Tí sa ich snažili často aj pod

43 Napríklad parlamentné návrhy a vystúpenia I. Hrušovského, J. Vrabca, M. Hodžu, J. Sopka a d'alších.

44 Podrobnejšie boli zachytené napr. aj ako výsledok porady o vyst’ahovalectve v roku 1928 , pozri podrobnejšie v Československé vystěhovalectví: jeho př́činy, důsledky a vyhlidky. Praha 1928, s. 108-109. Rovnako sa o problémoch a príčinách opakovane hovorilo v pléne Národného zhromaždenia, napr. poslanci I. Hrušovský, J. Vrabec a i.

45 ANM, of. A. Boháč, k. 5., nedat. list J. Auerhana, predsedu Československého ústavu zahraničného, adresovaný Predsedníctvu ministerskej rady v Prahe. 
nemeckým dohl'adom aplikovat' na slovenské pomery. Išlo napríklad o rasovú a diskriminačnú politiku voči židovskému, ale aj cigánskemu obyvatel'stvu. Zároveň ich inšpirovala aj nemecká propopulačná politika, idealizácia rodinného života, vzornej a príkladnej matky, ktorej hlavnou úlohou bolo rodit' a vychovávat' zdravé a silné deti. Tieto myšlienky sa následne pokúšali na Slovensku kombinovat' a presadzovat' so silnejším nacionálnym akcentom. ${ }^{46}$

Každodenný život obyvatel'stva Slovenska bol, popri politickej situácii, výrazne ovplyvňovaný stavom slovenského hospodárstva a zásobovaním. Tento faktor možno z pohl'adu vytvárania rodiny a rodinného života považovat' za jeden z kl’účových. Slovenské hospodárstvo vd’aka výhodnej štruktúre hospodárskych odvetví, nemeckým investíciám, vojnovej konjunktúre a zabezpečeniu odbytu pre pol’nohospodárske komodity do roku 1943 rástlo. ${ }^{47}$ Nasledujúce obdobie stagnácie už priamo súviselo s vojnovou situáciou a exploatáciou slovenského hospodárstva Nemeckom.

V medzivojnovom období, po odznení povojnovej kompenzačnej fázy, došlo k zvýrazneniu a dynamizácii transformačných zmien plodnosti, ku ktorým dochádzalo $\mathrm{v}$ rámci presadzovania procesu demografickej revolúcie. Z pohl’adu plodnosti išlo predovšetkým o výrazné znižovanie intenzity rodenia detí, a to najmä detí vyššieho poradia (štvrté a d'alšie deti), čo sa postupne začalo odzrkadl'ovat' aj na vel'kosti slovenskej rodiny. Práve znižovanie plodnosti a problematika menšieho počtu detí v rodine sa stala jednou z často pertraktovaných tém, ako aj dôležitou agendou oficiálnej propagandy v sociálno-spoločenskej oblasti. Pre koncepciu populačnej politiky pritom bola dôležitá aj skutočnost', že rozpadom Československa zanikla potreba riešit' populačné problémy s prihliadnutím na odlišne až protichodne sa demograficky vyvíjajúcu populáciu v západnej časti bývalého Československa. Rovnako marginálnymi sa stávali vnútorné rozdiely v reprodukcii, ked'že majoritné obyvatel'stvo slovenského štátu tvorilo obyvatel'stvo slovenskej národnosti, predstavujúce viac ako $80 \%$ prítomného obyvatel'stva. ${ }^{48}$

46 V tejto súvislosti zaujme najmä vyjadrenie Ernesta Rosivala, spravodajcu Sociálneho a zdravotného výboru Snemu Slovenskej republiky, ktorý pri obhajobe návrhu zákona o ochrane plodu 29. marca 1941 v sneme uviedol: „Populačnému tlaku nemeckému, plodnosti nemeckých matiek nemôže odolat' žiadna Maginotová linia a tá Francia, ktorá v dobe Napoleonovej tvorila $40 \%$ celého obyvatel'stva európskeho, v dobe Adolfa Hitlera musí ustúpit' podla prirodzeného vývojového zákona. “ Tesnopisecká zpráva o 60. zasadnutí Snemu Slovenskej republiky. Dostupné na: <http://www.nrsr.sk/dl/Browser/DsDocumentVariant?documentVariantId=42416\&fileName=zazn.pdf\&ext=pdf $>$. [cit. 2017-07-15].

47 MIČKO, Peter. Hospodárska politika Slovenského štátu: Kapitoly z hospodárskych dejín Slovenska v rokoch 1938 - 1945. Krakov: Spolok Slovákov v Pol’sku, 2010, s. 219 a n. ISBN 9788374903516.

48 ŠPROCHA, Branislav - TIŠLIAR, Pavol. Demografický obraz Slovenska v rokoch 1938 1945. Bratislava: Muzeológia a kultúrne dedičstvo, 2016, s. 140. ISBN 9788089881031. 
Jedným z výrazných hospodársko-sociálnych problémov, ktoré dlhodobo sužovali Slovensko, bola vysoká nezamestnanost'. V období Slovenskej republiky (1939 - 1945) došlo k jej výraznému poklesu prakticky na minimum, a to najmä vd’aka intenzívnej industrializácii, súvisiacej s vojnovou konjunktúrou, budovaním infraštruktúry a využitím slovenskej pracovnej sily v Nemeckej ríši ${ }^{49}{ }^{9} \mathrm{kde}$ vplyvom vojenského konfliktu chýbal dostatok pracovných síl, najmä v zbrojárskom, ale aj ostatnom priemysle. Rovnako v tomto smere pôsobilo aj uvol'nenie pracovných miest po vynútenom odchode českého obyvatel'stva zo Slovenska. Zahraničná pracovná migrácia sa tak síce zachovala, ale mala skôr dočasný charakter náborovej pracovnej migrácie. Migračný problém, ktorý sužoval medzivojnovú spoločnost' počas 2 . svetovej vojny takmer vymizol a nemusel byt' osobitne, politicky a koncepčne riešený. Navyše migračné pohyby výrazne limitoval samotný vojnový konflikt.

Nová populačná politika na Slovensku, ktorá sa tak začala utvárat' už na jeseň 1938, vychádzala z načrtnutej politickej a hospodársko-sociálnej situácie. Pomerne rýchlo sa vyformovala programová koncepcia aktívnej populačnej politiky, v mnohých ohl'adoch kopírujúca nemeckú propopulačnú politiku, ale v slovenskom prostredí so silným religióznym a konzervatívnym kontextom. A práve z týchto dôvodov v nej rezonovali najmä názory vychádzajúce z krest’anských zásad. ${ }^{50}$ Autoritatívny režim, ktorý sa na prelome 30. a 40. rokov na Slovensku presadil, z „národnej a krest’anskej“ pozície zdôrazňoval a propagoval rodinu, vyzdvihoval jej význam pre národ i štát. ${ }^{51}$ Dobový krest'anský konzervativizmus a učenie katolíckej cirkvi jednoznačne definovali nazeranie na populačný vývoj, reguláciu pôrodnosti a antikoncepciu, ale aj na úlohy a postavenie slovenskej ženy v rodine a spoločnosti. Prijímané právne normy a opatrenia mali za ciel' podporit' zakladanie slovenských rodín, podporit' pôrodnost' na jednej strane propagovaním viacdetných rodín a na druhej strane kritikou a odmietaním jednodetných alebo bezdetných manželstiev, ktorých počet sa koncom 30. rokov zvyšoval. Oslavám ženy matky bol každoročne v máji určený Deň matiek, v roku 1940 premenovaný na Deň slovenskej rodiny, ${ }^{52}$ ktorý podporoval kult

49 Podrobnejšie napr. MIČKO, Peter. Migrácia slovenskej pracovnej sily do Vel'konemeckej ríše. In ŠMIGEL', Michal - TIŠLIAR, Pavol a kol. Migračné procesy Slovenska (1918 1948). Banská Bystrica: Belianum, 2014, s. 287-288. ISBN 9788055708041.

50 HRNČIAROVÁ, Daniela - ŠKORVANKOVÁ, Eva. Ženy v období autonómneho Slovenska. In Historické štúdie. Bratislava: Stimul, 2013, s. 261-298. ISBN 9788022413244.

51 ŠKORVANKOVÁ, Eva. Propagácia materstva v období prvej Slovenskej republiky (1939 1945). In Populačné štúdie Slovenska 3. Bratislava: Muzeológia a kultúrne dedičstvo, 2014, s. 31-109. ISBN 9788097171506; ŠKORVANKOVÁ, Eva. Slovak women in the ideology and politics of the wartime Slovak Republic. In Women and World War II. Bratislava: STIMUL, 2016, s. 171-194. ISBN 9788081271700.

52 Tento sviatok sa oslavoval v medzivojnovom Československu od roku 1923. MVSR - Štátny 
„obetavých a statočných matiek “ ${ }^{53}$ Slávnosti sa konali v rámci celého Slovenska a poskytovali možnost' verejne demonštrovat' propagandu vládnucej elity venovanú materstvu a podpore rodiny. Rečníci oslavovali slovenské matky, ale zároveň kritizovali problém tzv. rozvracania rodín. ${ }^{54}$ Pri príležitosti Dňa slovenskej rodiny oceňoval prezident Jozef Tiso mnohodetné matky zvláštnym dekrétom..$^{55}$ Oslava rodinného života sa tak stala súčast'ou oficiálnej štátnej propagandy.

Opatrením, ktoré malo zastavit' vyššie spomínaný prepad plodnosti bol zásadný boj proti jej regulácii. Interrupcie patrili ešte z čias monarchie ku spoločnost’ou kritizovaným, „skrytým“ a trestným činnostiam. ${ }^{56} \mathrm{Na}$ Slovensku platil v medzivojnovom období uhorský zákonný článok o zločinoch a prečinoch z roku 1878, označovaný v medzivojnovom období často aj ako slovenský trestný poriadok. Za úmyselné vyháňanie plodu bola stanovená trestná sadzba väznenia na dva alebo tri roky, odstupňovaná podl'a toho, či išlo o tehotenstvo slobodnej alebo vydatej ženy. Potrestaná nebola len samotná žena, ale trestná sadzba 5 rokov bola určená aj pre realizátora zákroku. Pri úmrtí ženy po zákroku bola stanovená trestná sadzba na 15 rokov väzenia. ${ }^{57}$

V medzivojnovom období sa opakovane aj na pôde parlamentu diskutovalo o otázke liberalizácie prísnych protipotratových zákonov. Napriek početným pokusom niektorých poslankýň sa nepodarilo dosiahnut' reformu trestného zákona v otázkach trestnosti prerušenia tehotenstva. Po vyhlásení autonómie a následne po vytvorení Slovenského štátu sa tlak konzervatívnych politických a spoločenských kruhov zintenzívnil. Politici, právnici, lekári poukazovali na prudký nárast potratov v Československu a volali po sprísnení lekárskej praxe s potratmi. Po vzniku Slovenskej republiky (1939 - 1945) sa ochrane materstva venovala osobitná pozornost' aj v ústave. V §86 ústavy bola priamo deklarovaná zvýšená ochrana právneho poriadku manželstva, rodiny a materstva. ${ }^{58} \mathrm{~V}$ tlači sa spustila rozsiahla mediálna kampaň proti interrupciám. ${ }^{59}$ Vyskytli sa názory o nemrav-

archív v Košiciach,, pobočka Rožňava, f. Okresná starostlivost’ o mládež v Dobšinej, 1938 1945 (1947) (d’alej f. OSM Dobšiná), k. 1, bez sign.; tiež k. 2, bez sign.; tiež k. 3, bez sign.

53 Najkrajší sviatok srdca. In Nová žena, 11. júna 1939, roč. II, č. 24, s. 2-3.

54 Kto rozvracia rodiny, rozvracia spoločnost' l'udskú. In Slovák, 28. mája 1940, roč. XXII, č. 123 , s. 4.

55 Slovenský národ sa nemusí bát' vymierania: Vodca vzdal vd’aku slovenským matkám v mene národa. In Slovák, 30. mája 1943, roč. XXV, č. 124, s. 1. „Hlinkova slovenská l'udová strana vd'ači Vám za obetavost' a námahu, kterou ste slovenskému národu vychovali počet detí. “"

56 Zák. čl. V:1878 o zločinoch a prečinoch, \$285.

57 Zák. čl. V:1878, §§285, 286.

58 Ústavný zákon č. 185/1939 Sl. z., §86.

59 Katolícke noviny priniesli veriacim aj úryvky z pápežskej encykliky Pia XI. Casti Connubii o regulovaní pôrodnosti a interrupciách. Cirkevné stanovisko ohl'adne potratu. In Katolícke noviny, 2. marca 1941, roč. LVI, č. 9, s. 4. 
nosti bezdetných matiek alebo matiek len s jedným diet'at'om, ktoré ,,regulovali prírodu a zasahovali do Božieho diela" ". ${ }^{60}$

Napokon, výsledkom rozsiahlej kampane a diskusií o umelom ukončení tehotenstva a ochrane plodu, ktoré sa viedli nielen $\mathrm{v}$ sneme, $\mathrm{v}$ tlači, ale dá sa povedat', že rezonovali v celej spoločnosti, bol návrh zákona o trestných činoch proti l'udskému životu a proti jeho vzniku z októbra 1940, ktorý iniciovala slovenská vláda. ${ }^{61}$ Návrh zákona pripomienkovali rôzni odborníci a vedecké kapacity. Zásadné stanovisko poskytli predstavitelia Lekárskej fakulty Slovenskej univerzity, ktorí jednoznačne odmietli akékol'vek medicínske indikácie interrupcií (pôrodník prof. Michal Šeliga a neskorší rektor univerzity a internista prof. Emanuel Filo). ${ }^{62}$ Znalec kanonického práva, profesor teológie Alexander Špesz argumentoval zásadami krest’anskej morálky, podl'a ktorej usmrtenie plodu nebolo prípustné ani v záujme vyššieho dobra - v záujme záchrany života matky. V priebehu legislatívneho procesu získal vládny návrh zákona o ochrane plodu, jeho vzniku a o zmene $\S \S 285$ a 286 trestného zákona a $\S \S 423$ až 427 vojenského trestného zákona svoju finálnu podobu po zapracovaní pripomienok lekárov, právnikov aj predstavitel’ov katolíckej cirkvi. Vo vládnom návrhu zákona bolo umelé prerušenie tehotenstva zakázané a trestné. Zákon sprísňoval existujúce tresty za umelo vyvolané potraty u slobodnej ženy z dvoch na tri roky a u vydatej ženy z troch na pät' rokov väzenia. Vykonávatel' potratu mohol byt' odsúdený až na desat' rokov väzenia. Návrh pôvodne pripúšt’al, že v prípade vážneho ohrozenia života tehotnej ženy sa mohla interrupcia vykonat'. Dôvodilo sa, že ciel'om prijímanej zákonnej normy mala byt' najmä ochrana materstva a zvýšenie populácie. ${ }^{63}$ Napokon vstúpilo do platnosti také znenie zákona, ktorý úplne zakázal umelé ukončenie tehotenstva. ${ }^{64}$

Už v období autonómie sa otázka ochrany rodiny a podpory rodinného života začala posudzovat' v duchu krest’anskej morálky. ${ }^{65}$ Predseda autonómnej vlády Jozef Tiso vystúpil 21. februára 1939 s vládnym programom, v ktorom prezentoval ako základ sociálnej politiky slovenskej vlády starostlivost' o slovenské

60 DAFČÍK, Ján. Výchova dievčat v slovenskom štáte. In Kultúra, 1940, roč. XII, č. 1-2 (január - február), s. 27.

61 Vládny návrh zákona o ochrane plodu, jeho vzniku a o zmene $\S \S 285$ a 286 trestného zákona a $\S \S 423$ až 427 vojenského trestného zákona, Osnovy zákonov a nariadení, SNA, f. Snem Slovenskej republiky, k. 104, inv. č. 1245, II-6a/1-330.

62 SNA, osobný fond Emanuel Filo, (1925) 1935 - 1967 (1972), neusporiadaný fond, bez sign.

63 Tesnopisecká zpráva o 60. zasadnutí Snemu Slovenskej republiky. Dostupné na: <http:// www.nrsr.sk/dl/Browser/DsDocumentVariant?documentVariantId=42416\&fileName=zazn. pdf\&ext=pdf $>$. [Stav 15.7.2016].

64 Zákon č. 66/1941 Sl. z. o ochrane plodu, jeho vzniku a o zmene §§ 285 a 286 trestného zákona a $\S \$ 23$ až 427 vojenského trestného zákona.

65 HRNČIAROVÁ - ŠKORVANKOVÁ, ref. 50, s. 261-298. 
rodiny. Vládne vyhlásenie vymedzilo aj úlohu ženy v slovenskej spoločnosti. Slovenské ženy sa mali realizovat' predovšetkým v súkromnej sfére, v usporiadanej krest’anskej rodine, po boku manžela a pri výchove detí. ${ }^{66}$ Prostriedkom $\mathrm{k}$ upevneniu slovenskej rodiny sa mala stat' aj politika prepúšt'ania vydatých žien z pracovného pomeru, podpora sobášnosti, pôrodnosti a zakladania rodín i sociálna politika autonómnej vlády.

Po 14. marci 1939 slovenská politická elita mohla v tejto politike pokračovat' a definované ciele realizovat' v praxi. Slovenská vláda si dala za ciel' postupne zlepšovat' podmienky zakladania nových rodín, najmä zlepšovaním možností ich hmotného zabezpečenia. Podmienky rodinného života mali vylepšovat' rodinné prídavky, odstupňované podl'a počtu detí (tzv. rodinné mzdy), ktorých jedným $\mathrm{z}$ ciel'ov malo byt' aj odbremenenie ženy od zamestnania a jej návrat $\mathrm{k}$,,rodinnému krbu“. Zavedenie „rodinných miezd“ sa stalo súčast'ou programového vyhlásenia Tukovej vlády z 21 . novembra $1939 .{ }^{67}$ Spočiatku sa týkali robotníckych rodín, no s narastajúcou infláciou a cenovou hladinou boli riešené aj v prípade štátnych zamestnancov a úradníkov. Okrem pravidelne vyplácaných rodinných prídavkov štát organizoval aj jednorazové zimné výpomoci, rôzne dobročinné a charitatívne organizácie zimné zbierky a výpomocné akcie.

Na rodinné prídavky, resp. zimnú výpomoc ale nemalo nárok perzekvované židovské a cigánske obyvatel'stvo. Totalitný režim nemal záujem na zvyšovaní počtu osôb týchto etník. Postupné sprísňovanie perzekúcie židovského a cigánskeho obyvatel'stva viedlo až $\mathrm{k}$ rasovo motivovaným opatreniam, ku konfiškáciám majetku, vytváraniu pracovných táborov, no najmä $\mathrm{k}$ deportáciám.

\section{Záver}

Populačnú politiku, ktorá sa uplatňovala na území Slovenska možno po roku 1918 rozdelit' prakticky do dvoch častí. V prvej, ktorá prebiehala v medzivojnovom období, ked’ bolo územie Slovenska súčast’ou Československej republiky, bola typická protichodnost' populačných opatrení. Tie boli prakticky reakciou na odlišné potreby jednotlivých populácí žijúcich v Československej republike vychádzajúcich z odlišného časovania nástupu demografickej tranzície (revolúcie). Tá znamenala prechod od extenzívnej k intenzívnej plodnosti, k zníženiu manželskej plodnosti, a teda aj $\mathrm{k}$ zníženiu počtu detí v rodine a $\mathrm{k}$ celkovému zlepšeniu úmrtnostných pomerov. Tieto zmeny napokon nastali v každej populácii

66 Vyhlásenie vlády Slovenskej krajiny. In FABRICIUS, Miroslav - HRADSKÁ, Katarína. (eds.). Jozef Tiso :Prejavy a články. Zv. II (1938 - 1944). Bratislava: AEP, 2007, s. 77. ISBN 8088880467.

67 Tesnopisecká zpráva o 15. zasadnutí snemu Slovenskej republiky. Dostupné na: $<$ http://www. nrsr.sk/dl/Browser/DsDocumentVariant?documentVariantId=28647\&fileName=zazn.pdf\&ext=pdf $>$. [cit. 2016-07-15]. 
Československa, ale v inom období, čo si vyžadovalo rozdielne posudzovat' ich potreby a priority v populačnej politike. Práve toto možno považovat' za dôvod, prečo sa $\mathrm{v}$ medzivojnovom období nevytvorila účinnejšia koncepcia populačnej politiky a pôsobila protichodne (na jednej strane podpora rodín k zvýšeniu plodnosti, na druhej organizovaná pomoc k vyst'ahovaniu obyvatel'stva trpiacom nezamestnanost'ou).

Situácia sa zmenila rozpadom Československa po udalostiach v rokoch 1938/1939, ked' na Slovensku po územných zmenách majoritný národ predstavoval výraznú väčšinu. Vytvorit’ koncepciu štátnej populačnej politiky bolo na jednej strane jednoduchšie, na druhej sa pri jej utváraní prejavili radikálne prvky, zahraničný vzor, ale aj agresivita vo vzt’ahu k vybraným skupinám spoločnosti.

Populačná politika na Slovensku v 1. polovici 20. storočia tak prešla viacerými formami a zmenami. V priebehu relatívne krátkeho obdobia sa tu vystriedal populacionizmus, neomalthuzianizmus, neskôr nacionalizmus spojený s vybranými krest’anskými zásadami a napokon aj výrazné prvky rasizmu, segregácie častí spoločnosti, pre ktoré sa „výhody“ mierené na podporu rodín, nevzt'ahovali. Pritom všetky tieto čiastkové populačné politiky u nás neexistovali izolovane, ale prelínali sa.

* Príspevok je výsledkom riešenia grantovej úlohy MŠ SR VEGA č. 1/0113/17 Populačná a rodinná politika na Slovensku v 20. a 21. storočí.

\section{TRENDS UND DIE AUSRICHTUNG DER BEVÖLKERUNGSPOLITIK} IN DER SLOWAKEI IN DEN JAHREN 1918-1945

PAVOL T I Š L I A R - BRANISLAV Š P R O C H A - EVA ŠK O RVA N K O V Á

Die Bevölkerungspolitik auf dem Gebiet der Slowakei lässt sich nach 1918 praktisch in zwei Perioden aufteilen. Für die erste Periode in der Zwischenkriegszeit, als das Gebiet der Slowakei Bestandteil der Tschechoslowakischen Republik war, wurde die Gegensätzlichkeit der Bevölkerungsmaßnahmen kennzeichnend. Sie waren praktisch die Reaktion auf die unterschiedlichen Bedürfnisse der einzelnen Populationen, die in der Tschechoslowakischen Republik lebten, die auf einer unterschiedlichen zeitlichen Bestimmung des Antritts der demografischen Transition (Revolution) basierten. Sie bedeutete den Übergang von der extensiven zur intensiven Fruchtbarkeit, zur Senkung der ehelichen Fruchtbarkeit und somit zur Senkung der Anzahl der Kinder in der Familie und zur allgemeinen Verbesserung der Sterblichkeitsverhältnisse. $\mathrm{Zu}$ diesen Änderungen kam es schließlich in jeder Population der Tschechoslowakei, jedoch nicht zu gleicher Zeit, was eine unterschiedliche Beurteilung ihres Bedarfs und ihrer Priorität in der Bevölkerungspolitik erforderte. Eben das könnte der Grund dafür 
sein, warum in der Zwischenkriegszeit keine wirksamere und einheitliche Konzeption der Bevölkerungspolitik, die widersprüchlich wirkte (Unterstützung der Familien zur Erhöhung der Fruchtbarkeit einerseits und organisierte Hilfe bei der Aussiedlung der Bevölkerung, die unter der Arbeitslosigkeit litt), geschafft wurde.

Die Situation änderte sich durch den Zerfall der Tschechoslowakei nach den Ereignissen in den Jahren 1938/1939, als die Majoritätsnation in der Slowakei nach den Gebietsänderungen eine deutliche Mehrheit darstellte. Die Bildung einer Konzeption der staatlichen Bevölkerungspolitik wurde einerseits einfacher, anderseits machten sich bei ihrer Schaffung radikale Elemente der Ludaken-Ideologie, ausländisches Vorbild sowie Aggressivität gegenüber bestimmten Bevölkerungsgruppen (Juden, Zigeuner/Romas) bemerkbar.

Die Bevölkerungspolitik in der Slowakei in der ersten Hälfte des 20. Jahrhunderts machte mehrere Formen und Änderungen durch. Im Laufe einer relativ kurzen Zeit wechselten sich hier Populationismus, Neomalthusianismus, später Nationalismus in Verbindung mit ausgesuchten christlichen Grundsätzen und schließlich auch markante Elemente des Rassismus, Segregation der Gesellschaftsgruppen, auf die sich die „Vorteile“ zur Unterstützung der Familien nicht bezogen. Dabei existierten diese Teilbevölkerungspolitiken bei uns nicht isoliert, sondern sie überschnitten sich.

prof. PhDr. Pavol Tišliar, PhD.

Katedra etnológie a muzeológie

Filozofická fakulta Univerzity Komenského v Bratislave

Ústav archeologie a muzeologie

Filozofická fakulta Masarykovej univerzity v Brne

e-mail: pavol.tisliar@uniba.sk

RNDr. Branislav Šprocha, PhD.

Centrum spoločenských a psychologických vied SAV

Výskumné demografické centrum pri INFOSTAT-e

e-mail: branislav.sprocha@gmail.com

Mgr. Eva Škorvanková, PhD.

Katedra všeobecných dejín

Filozofická fakulta Univerzity Komenského v Bratislave

e-mail: eva.skorvankova@uniba.sk 